\title{
PENSAR A LEGITIMIDADE DA JURISDIÇÃO CONSTITUCIONAL EM TEMPOS DE CRISE DE POLÍTICA
}

\author{
THINKING ABOUT THE LEGITIMACY OF JUDICIAL REVIEW IN \\ TIMES OF POLITICAL CRISIS
}

Diogo Bacha e Silva

Alexandre Gustavo Melo Franco Moraes Bahia

\section{RESUMO}

0 presente trabalho procura observar a legitimidade da jurisdição constitucional em tempos de crise política. Refletimos sobre o nascimento da jurisdição constitucional enquanto parad oxo e a problemática discutida sobre sua legitimidade. Em tempos de crise política, o subsistema político provoca irritações sistêmicas fazendo surgir semânticas novas que a jurisdição constitucional deve transformar em comunicações jurídicas. Identificamos o populismo judicial e a primazia dos argumentos econômicos como novos elementos que provocam crise na legitimidade democrática da jurisdição constitucional.

Palavras-chaves: Jurisdição constitucional. Crise política. Populismo judicial. Paradoxos. Teoria dos sistemas.

\section{ABSTRACT}

The present work tries to observe the legitimacy of the judicial review in times of political crisis. We reflect on the birth of judicial review as a paradox and the problematic discussed about its legitimacy. In times of political crisis, the political subsystem causes systemic irritations, bringing forth new semantics 
that judicial review must transform into legal communications. We identify judicial populism and the primacy of economic arguments as new elements that provoke crisis in the democratic legitimacy of judicial review.

Keywords: Judicial review. Political crisis. Judicial populism. Paradoxes. System`s theory.

\section{INTRODUÇÃO}

Desde 2013 atravessamos um momento jurídico-político delicado no país, o que ocasionou uma forte crise política aliada a uma mudança de postura do Poder Judiciário. No plano político, podemos citar as manifestações populares contra o regime político instaurado no país, impeachment de uma Presidente legitimamente eleita sem qualquer comprovação de crime de responsabilidade, envolvimento de grande número de parlamentares em denúncias de corrupção ainda sob a vigência do mandato dos partidos políticos mais importantes no cenário político, denúncia contra ex-presidentes e importantes figuras tidas como presidenciáveis de cometimento de delitos (CATTONI DE OLIVEIRA; BACHA E SILVA; BAHIA;2016a). No plano jurídico, citamos juiz de primeira instância que se outorga como herói da nação desbordando de suas competências jurisdicionais para a prática de atos jurisdicionais que se curvam as interesses populares (ou midiáticos?) ao mesmo tempo em que violam a Constituição e demais normas (CATTONI DE OLIVEIRA; BACHA E SILVA; BAHIA;2016b). A isso se some o Supremo Tribunal Federal sendo, no mínimo, omisso em relação à proteção dos direitos fundamentais e, quando lhe aprove, prolatando decisões que contrariam o texto constitucional, permitindo o retrocesso em conquistas civilizatórias importantes - como na decisão sobre a "relativização" da presunção de inocência.

O cenário parece ser de desordem, de caos, tanto do ponto de vista jurídico quanto do ponto político. Retrocessos nos direitos conquistados as duras penas ao longo de toda a história, corrupção endêmica (agora exposta), crise econômica que assola os setores público e privado. 
No pensamento popular um sentimento de desapreço à política e ao direito, uma certa desconfiança, uma ideia de que a república e a democracia não são instituições originárias deste país, sentimento que pode ser transmitido com facilidade pela literatura assim como já fazia o personagem Policarpo Quaresma de Lima Barreto no início do século XX.

De outro lado, o pensamento jurídico também demonstra sentimentos de estranhamento e de descredibilidade com o Poder Judiciário, Ministério Público e às demais instituições que deveriam se valer do direito como transformação social. 0 ideário é de que o Direito foi capturado pela política e pela economia para manutenção de privilégios.

Nosso objeto de análise aqui é saber como se dá a legitimidade da jurisdição constitucional quando há grande descredibilidade na defesa e proteção da Constituição. Após muitas discussões que vão desde Alexis de Tocqueville no século XVIII até as discussões do século XXI de Mark Tushnet, Larry D. Kramer e Cass Sunstein, por exemplo, passando por Hans Kelsen, Carl Schmitt, Jürgen Habermas e Carlos Santiago Nino, dentre outros, a legitimidade da jurisdição constitucional é assunto central na Teoria da Constituição e do Estado. De qualquer forma, não há uma resposta definitiva sobre como o judicial review pode se tornar um momento democrático. E, aqui, reside o problema do presente artigo.

Em tempos de crise de representatividade política a sociedade delega esperanças a outros órgãos que estão, em princípio, libertos da lógica da representatividade. Por isso, por exemplo, na atualidade, a sociedade demonstra confiança em órgãos como Ministério Público, Polícia Federal e Poder Judiciário. Longe da lógica política, tais órgãos representam um espaço de esperanças na transformação social longe do foco político propriamente dito - o que levanta questões muito sérias pois que, como instituições não eleitas, sua legitimidade deriva unicamente da Constituição mas não passa pelo crivo da representação popular. Se os "inputs" da vontade pública não passam pelo debate da política, de forma que possam ser discutidos e filtrados para, então, serem traduzidos no código próprio do direito mas, ao revés, se pretende que passem diretamente da periferia para os órgãos de execução, então a política perde seu papel - e, logo, a democracia, pois é que na política onde esta se realiza do ponto de vista institucional -, e ainda se corre o risco de 
que apenas alguns setores dessa sociedade (e, pois, apenas alguns temas) sejam captados (e não outros) e ainda mais, sem debate com posições contrárias (NOVAES, 2007).

A pesquisa empreendida procura levantar a problemática da legitimidade da jurisdição constitucional no Brasil em tempos de crise política e abordar algumas possíveis soluções teóricas para problemas práticos vivenciados no constitucionalismo e democracia contemporâneos. Vale destacar, no entanto, que mesmo quanto a esses órgãos os supostos de neutralidade/paixão ideológica já não são tão exatos na medida em que operações, ações e decisões não raramente se colocam como resposta à crítica pública. 0 compromisso do Judiciário - assim como dos demais entes judiciários acima mencionados - deve ser, sempre, com a Constituição e não com a (suposta) opinião pública. Por isso, por exemplo, são dadas garantias constitucionais aos juízes, que não dependem de voto para exercerem suas funções e têm garantidos o cargo e os vencimentos independentemente de agradarem/não entes políticos, mídia ou "opinião pública”.

Acreditamos, pois, que o texto não solucionará a questão de uma vez por todas e todo de uma vez. A razão e a verdade como sapere aude, típica do iluminismo, não passam de um sonho infantil que desconsidera a dinâmica histórica das relações entre poder e saber. Por isso, ao segundo leitor - já que encaramos a perspectiva de que o autor é sempre o primeiro intérprete de sua obra - resta a advertência de que os problemas da legitimidade da jurisdição constitucional estão sempre porvir.

\section{PROBLEMAS DE TEORIA POLÍTICA E TEORIA DA CONS- TITUIÇÃO: A JURISDIÇÃO CONSTITUCIONAL ENQUANTO PARADOXO}

Para a consecução do objetivo, necessário um recorte epistemológico na própria definição de jurisdição constitucional. Em primeiro lugar deve-se compreender que jurisdição constitucional pode ter um sentido amplo, na exata medida em que não há aplicação do direito, dentro de um Estado Democrático de Direito (art. 1ํo da CF/88), que não seja exercício de jurisdição constitucional. Todo exercício da jurisdição deve 
ser jurisdição constitucional, sob pena de grave afronta à Constituição (MAGALHÃES, 2009, p. 143), principalmente em países, como o Brasil, em que qualquer juiz diante de um caso pode/deve deixar de aplicar normas se estas confrontarem a Constituição - logo, todo juiz aqui é um juiz constitucional, não havendo de se falar em uma jurisdição não constitucional. Aqui, no entanto, as referências à jurisdição constitucional serão tomadas em um sentido mais estrito, como, por exemplo, define Hans Kelsen enquanto garantia jurisdicional da Constituição, enquanto um conjunto de medidas técnicas que tem por fim garantir o exercício regular dos poderes constituídos e da força normativa da Constituição (KELSEN, 2007, p. 123-124). Jurisdição constitucional, portanto, quer dizer, para nosso intento, apenas o controle de constitucionalidade ou o judicial review como busca de garantia da Constituição.

A primeira questão que sobressai é da legitimidade da jurisdição constitucional. 0 princípio republicano consagra o controle de constitucionalidade como núcleo central para a limitação dos poderes e a instituição de um federalismo. Não é à toa, pois, que o controle de constitucionalidade somente foi pensado e implementado entre nós com a Constituição de 1891 quando, supostamente, se implementaram o regime republicano e o federalismo(ALMEIDA, 2010).

Com efeito, já no seu clássico trabalho sobre jurisdição constitucional, Hans Kelsen pensava o instituto a partir da coexistência de uma pluralidade de ordens jurídicas, para dizer que somente com a jurisdição constitucional o Estado federativo é plenamente realizável. Nesta espécie de Estado, a descentralização da ordem jurídica é o núcleo essencial da Constituição. Qualquer que fosse a violação desses limites traçados seria também violação ao pacto federativo (KELSEN, 2007, p. 182-183).

$\mathrm{Na}$ origem dos debates da Constituição norte-americana, a problemática do judicial review é colocada nos termos democráticos. No artigo de número 78 dos Federalistas, Alexander Hamilton não nega a necessidade de se conceder ao Poder Judiciário a possibilidade de anular atos legislativos contrários à Constituição, mesmo estatuindo a assertiva de que o Poder Judiciário é o mais fraco entre os poderes. A questão, no entanto, é que a Constituição fixa o Poder Judiciário entre o povo e seus representantes, com o objetivo de conter a legislatura nos 
parâmetros fixados constitucionalmente (HAMILTON; MADISON; JAY; 2003, p. 459-460).

Difícil demarcar na história do constitucionalismo ocidental um marco temporal para o surgimento do controle de constitucionalidade, sendo construção histórica e marcada por esquemas institucionais próprios a cada momento histórico (BACHA E SILVA, 2013; MACGREGOR, 2010; CAPPELLETTI, 1999). Mesmo que alguns autores busquem inspiração histórica na sociedade grega para o controle de constitucionalidade (CRUZ, 2004, p. 34), é demasiado complicado ler os institutos de uma sociedade tão singular e distinta tal como era a Grécia Antiga de acordo com os institutos de nossa sociedade. É o caso de uma leitura histórica anacrônica.

Estruturalmente, consolidam-se dois esquemas institucionais próprios do controle de constitucionalidade e de exercício da jurisdição constitucional. 0 primeiro modelo de origem estadunidense, muito embora não previsto na Constituição norte-americana de 1787, tem seu marco no histórico julgamento Marbury x Madison (1803), em que John Marshall conferiu competência ao Poder Judiciário para anular atos legislativos contrários à Constituição (ENTERRÍA, 2006). É bem verdade que a referida decisão que propagou para o mundo o judicial review, apesar das circunstâncias fáticas envolvidas, foi muito mais fruto do acaso ou da sagacidade política de John Marshall (MACIEL, 2006). Uma necessidade política contingencial e o judicial review propagou-se para o mundo, consolidando um modelo institucional de exercício da jurisdição constitucional.

O outro modelo institucional é de matriz europeia e tem como origem o pensamento de Hans Kelsen e aplicação prática na Constituição Austríaca de $1^{\text {o }}$ de outubro de 1920, com a criação de uma Corte Constitucional, cuja função seria fiscalizar a constitucionalidade das leis, sendo um poder autônomo entre os demais, já que seria um legislador negativo (KELSEN, 2007). Aqui já não se trata de órgão pertencente ao Poder Judiciário, mas sim um poder distinto dos tradicionais, embora sua denominação de Corte.

Razões de ordem histórica e política explicam a não recepção do judicial review no velho continente. Em primeiro lugar, o triunfo da soberania popular nas Revoluções Gloriosa e Francesa colocaram o 
parlamento como órgão que encarnava a soberania do povo, tendo em conta a representatividade política desses órgãos (RAMOS, 2010, p. 124). Como consequência da supremacia parlamentar, havia um clima de desconfiança com os demais poderes já que representavam o ancien régime, ou seja, tudo aquilo que os revolucionários buscaram superar ${ }^{1}$.

É com o pós-guerra que o controle de constitucionalidade de matriz eurocêntrica consolida-se e se reforça como um meio institucional de exercício da jurisdição constitucional. A Lei Fundamental de Bonn de 1949, a Constituição da Itália de 1947, a Constituição Espanhola de 1978 e a de Portugal de 1976 são exemplos de reforço como meio institucional importante de exercício da jurisdição constitucional concentrada. Um dos últimos redutos europeus de resistência ao controle de constitucionalidade concentrado, a França, acabou incorporando elementos do controle de constitucionalidade europeu com a reforma constitucional de 2008 que inseriu a question prioritaire de constitutionnalité no art. 61-1 da Constituição Francesa (GUILLAUME, 2010).

Consolidado os meios institucionais de exercício da jurisdição constitucional, os teóricos passam a se debruçar acerca da compatibilidade entre o exercício da defesa da Constituição pelo Poder Judiciário e a ideia de um regime democrático. Embora todos os órgãos públicos sejam responsáveis pela aplicação da Constituição, a partir da segunda guerra mundial, todas as expectativas são depositadas no Poder Judiciário que, de uma forma ou de outra, deve exercer seu mister de acordo com os parâmetros democráticos.

Assim, a própria formação histórica do controle de constitucionalidade serviu para transformar problemas políticos em problemas jurídicos, submetidos ao código binário lícito ou ilícito. A partir, sobretudo, da ideia de uma Constituição em sentido formal, como norma superior às demais, realizando o acoplamento estrutural entre direito e política acarretou-se o resultado de uma catástrofe em sentido luhmanniano (LUHMANN, 1996). De outro modo, com Luhmann, se pode dizer que a Constituição alcança soluções políticas para o problema da autorreferência do direito e soluções jurídicas para o problema da autorreferência política (LUHMANN, 2005, p. 548). 
No entanto, há uma tendência fatal no surgimento dos paradoxos que insistem em aparecer, apesar das transformações semânticas, no sistema jurídico. Certamente, um desses paradoxos do direito é a ideia de jurisdição constitucional ou judicial review. Para salvar a democracia eliminamos a lógica política, colocando-a sobre a lógica jurídica. Isto é, a democracia enquanto instituto pensado na política, agora sai das comunicações políticas, passando para as comunicações jurídicas. Para salvar a democracia é preciso se livrar da democracia. Retirar questões políticas do seu lugar de discussão e transferi-las para o Judiciário é uma escolha perigosa.

Os sistemas constitucionais do pós-segunda guerra, ao fortalecerem formas de controle judicial de constitucionalidade para a proteção de um rol cada vez maior de direitos fundamentais e de Constituições que passam a tratar, em pormenor, de questões políticas e econômicas - em um contexto de Estados Nacionais com grande intervenção sobre o mercado e a vida "privada" -, fizeram com que questões tradicionalmente "políticas" migrassem para o debate "jurisdicional" - algo que é normalmente conhecido como "judicialização da política" ou "politização do judiciário".

Debates já encerrados nos Parlamentos e proposições minoritárias derrotadas da "oposição" face o Executivo retornam ao mundo via Judiciário. Este, por sua vez, como é o único subsistema do sistema do direito que não pode deixar de decidir; durante muito tempo (no Brasil) ele se eximiu de entrar no mérito alegando se tratarem de "questões políticas". No entanto, a partir da segunda metade dos anos 1990, mudou seu entendimento e vem sistematicamente decidindo questões que envolvem decisão sobre aplicação e realocação de recursos públicos. Tal mudança pode ser vista sob uma perspectiva positiva, isto é, de cumprimento das promessas constitucionais de plenitude de direitos fundamentais ou de forma mais cética, apontando-se uma série de problemas, desde a seletividade dos beneficiados pelas decisões (notadamente no caso da saúde) até excessos e puro ativismo judiciário (quando este se substitui na função legislativa e passa a ditar decisões de caráter normativo à revelia de limites constitucionais) (BAHIA, BACHA E SILVA, 2016; PINTO, BAHIA, SANTOS, 2017; BAHIA, BACHA E SILVA, NUNES, GOMES, 2015).

Será, então, que há alguma medida para desparadoxar este paradoxo, uma terceira via na jurisdição constitucional? Isso porque, como 
diz Luhmann, "existem paradoxos em todos os lugares, sempre que procuramos fundamentos. 0 problema fundamental encontrado no Direito, então, não é encontrar e identificar o motivo máximo ou razão que justifique sua existência. 0 problema é como suprimir ou atenuar o paradoxo no qual um observador com tendências lógicas ou com um grau suficiente de insatisfação poderia ver e articular a qualquer hora" (LUHMANN, 2006, p. 46).

As observações de um observador da Teoria Crítica Constitucional de matriz decolonial tal qual fazem, por exemplo, Ricardo Sanin Restrepo e Gabriel Méndez Hincapie de que "desde la sentencia fundante de la supremacía judicial Marbury V. Madison, el contenido político de la Constitución se comprime y se transforma en un contenido netamente tecno-jurídico (ley ordinária)" (RESTREPO, HINCAPIE, 2012, p. 110), transformando a Constituição em instrumento para poucos indivíduos a serviço do poder dominante, já que utiliza a linguagem do Direito, muito embora sejam perspectivas interessantes, não resolvem o problema do paradoxo.

Qual seria, então, o terceiro caminho da legitimidade da jurisdição constitucional ao invés de se buscar um fundamento para ela? Qual o futuro da jurisdição constitucional? Teriam irritações sistemáticas na jurisdição constitucional em épocas de crise política? Como o exercício da jurisdição constitucional poderia se livrar de sua semântica paradoxal?

A grande questão é a legitimidade no exercício da jurisdição constitucional e não a legitimidade institucional da jurisdição constitucional, já que esta última parece ser um dogma da sociedade moderna (BONAVIDES, 2004).

\section{CRISE POLÍTICA E JURISDIÇÃO CONSTITUCIONAL: AS IRRITAÇÕES SISTÊMICAS PROVOCADAS PELO SISTEMA POLÍTICO}

A questão é complexa e, ao mesmo tempo, paradoxal. É que a jurisdição constitucional, como regra, quando julga uma lei inconstitucional atua contra a vontade da maioria (BICKEL, 1986, p. 17). Se considerarmos que os Direitos Fundamentais são "trunfos", como quer Dworkin, a 
função contramajoritária dos Tribunais não se mostraria problemática, em princípio, quando aqueles tiverem que escolher entre proteger direitos fundamentais-constitucionais ou a vontade atual/efêmera de uma maioria representada no Parlamento.

No entanto, a atuação da jurisdição constitucional pode ser tornar problemática se a Corte Constitucional (ou similar) se torna a guardiã da moralidade da sociedade, buscando atuar como um órgão estatal que, longe dos procedimentos democráticos, quer se tornar a última instância moral de uma sociedade órfã (MAUS, 2010, p. 8)².

É essa ideia que norteia a desconfiança de Habermas quanto ao controle de constitucionalidade. Muito mais por acreditar que a Corte Constitucional, ao interpretar as normas constitucionais, pode se apropriar da democracia e tendo em conta seu esforço de reconstrução teórico-prática de uma sociedade democrática em meio à modernidade, é que o filósofo alemão tem a firme convicção de que o controle de constitucionalidade deve servir para a proteção das condições do exercício da cidadania, entendida como uma cooriginalidade entre autonomia pública e privada, ou seja, sob os pressupostos teóricos de Habermas, o Tribunal Constitucional deve garantir o exercício da formação da vontade pública, permitindo o desenvolvimento de uma prática comunicativa orientada para a formação da opinião e vontade públicas (HABERMAS, 2010, p. 354) 3 .

Não à toa, portanto, Habermas é um ferrenho crítico da aplicação da ponderação alexyana pelos Tribunais Constitucionais, chegando mesmo à assertiva de que a teoria tem caráter axiológico, sendo absolutamente contrário ao caráter deontológico do direito (HABERMAS, 2010, p. 326 e ss). A saída habermasiana é reconciliar jurisdição constitucional e democracia, no sentido de que o controle de constitucionalidade só se afirma como garante das condições procedimentais da formação da opinião e vontade públicas, realizando o controle do devido processo legislativo (CATTONI DE OLIVEIRA, 2016).

Alexy, criticado por Habermas, tenta salvar o paradoxo da legitimidade democrática da jurisdição constitucional com enfoque no conteúdo de suas decisões. Diferenciando entre, de um lado, a representação argumentativa e, de outro, a representação volitiva, diz Alexy que a jurisdição constitucional se compatibiliza com o ideal democrático na medida em 
que, enquanto o Parlamento representa o povo democraticamente, o Tribunal Constitucional o representa argumentativamente, conciliando as dimensões ideal e real do direito (ALEXY, 2005, p. 579). Neste aspecto, a jurisdição constitucional será democrática se sua argumentação levar em conta o direito positivo e a pretensão de correção, de acordo com uma concepção não-positivista do direito (ALEXY, 2009). Por óbvio, muito embora a argumentação jurídica seja elemento importante dentro da dinâmica decisória, ante a garantia da fundamentação das decisões, sua correção lógico-analítica não assegurará uma decisão democrática. A possibilidade de inserção de argumentos morais, políticos e econômicos na decisão da jurisdição constitucional e a corrosão da autonomia do direito fazem com que a tese de Alexy não assegure uma decisão legítima.

A discussão acadêmica estadunidense acerca da legitimidade do judicial review também costuma se fincar em dois lados opostos que, por aqui, se convencionou rotular de procedimentalismo vs. Substancialismo (SIMIONI, 2014). Somos absolutamente contrários a tais rótulos que, de um modo geral, não apreendem as diversas teorias sobre a legitimidade do judicial review - além de simplificarem autores e teorias para que "caibam" em tais designações.

Dworkin, por exemplo, defende a teoria de que a jurisdição constitucional deve realizar uma leitura moral da Constituição, sempre julgando por princípios e nunca por políticas. A Constituição seria o local onde as questões fundamentais da sociedade podem ter uma resposta jurídica correta (DWORKIN, 2005, p. 101). Muito embora Dworkin livre a jurisdição constitucional de uma resposta final e definitiva, já que permite o erro dos juízes, a coerência e integridade do direito levam a uma atitude contrafactual no exercício de jurisdição por Hércules (DWORKIN, 2010, p. 82).

Já o constitucionalista John Hart Ely entende que as decisões fundamentais da sociedade devem ser tomadas pela comunidade de cidadãos, portanto, as cortes constitucionais devem apenas controlar os procedimentos de produção de decisões (ELY, 2010). Jeremy Waldron acredita que o controle de constitucionalidade forte seria despiciendo, já que os dissensos tanto de razões de conteúdo ou de procedimentos devem ser resolvidos pela arena legislativa. Nenhuma razão, diz ele, determina que o Poder Judiciário oferece a melhor proteção aos direitos individuais 
(WALDRON, 2006). Para o autor um controle fraco de constitucionalidade em que o Poder Legislativo poderia superar a decisão da jurisdição constitucional serviria para diminuir as críticas ao controle de constitucionalidade (WALDRON, 2017).

Essas discussões teóricas norte-americanas levaram a uma crítica em face da supremacia judicial. Naquilo que se convencionou denominar de constitucionalismo popular, as críticas são acerca da última palavra acerca da interpretação da Constituição ficar com o Poder Judiciário, instituição que foge da lógica da democracia representativa, e, pois, dessa forma, não poderia ser o órgão responsável por resolver os desacordos morais razoáveis de uma vez por todas.

Nessa linha, por exemplo, o pensamento de Larry Kramer para quem o que deve acontecer no constitucionalismo popular é uma mudança na autopercepção dos juízes das Cortes Constitucionais que levaria, inevitavelmente, a uma mudança também na atitude e decisões judiciais. A autoridade das decisões judiciais depende, de certa maneira, da reação dos outros poderes e, principalmente, do povo. A pressão popular pode fazer com que a Corte Constitucional se sinta responsável diante do povo, sabendo que ali fora há cidadãos reais e não em abstrato (KRAMER, 2011, p. 307-308). Assim também o pensamento de Robert Post e Reva Siegel no sentido de que a interpretação das normas constitucionais deve ser uma forma de realizar o complexo processo de autodeterminação do povo, no exato sentido de que as reações às decisões da Corte Constitucional podem servir para um engajamento energético do povo no processo político de condução da sociedade (POST, SIEGEL, 2004).

A questão da legitimidade é pensada por todos estes autores universalmente. Suas hipóteses são trabalhadas tendo como pressuposto o regular funcionamento democrático das instituições, como se as contingências políticas não fossem capazes de alterar o pensamento sobre a jurisdição constitucional.

Sendo a Constituição o acoplamento estrutural entre política e direito, é decorrência lógica que poderá haver irritação sistêmica entre os subsistemas política e direito que impactarão diretamente na jurisdição constitucional enquanto atividade voltada à interpretação da Constituição. 
A diferença entre ambiente e entorno do sistema produz autonomia ao direito. No entanto, a autonomia não significa que este não poderá transformar outputs em inputs. A diferenciação funcional da sociedade faz com que cada subsistema trabalhe de acordo com sua própria comunicação. A clausura operativa impele com que cada sistema da sociedade realize uma diferenciação comunicativa entre o ambiente e seu entorno ${ }^{4}$.

As irritações sistêmicas ganham sentido na teoria da sociedade dentro da clausura operativa de cada sistema, isto é, o fato de que cada sistema funciona de acordo com suas próprias comunicações. Receber as irritações de outros sistemas pressupõe que o sistema se mantém aberto as modificações semânticas, isto é, mantem-se aberto ao aprendizado de outros sistemas e, com isso, a possibilidade de evoluir ou modificar suas estruturas $^{5}$. Por isso, as irritações provocam estruturas de expectativas para a resolução dos problemas.

Os problemas relacionados à teoria política tal qual se levantam novas conotações semânticas e o aparecimento de novos problemas políticos são irritações do sistema político para o sistema jurídico que deverá transformar tais problemas do entorno em código de comunicação do direito.

Assim, portanto, a crise política que vivenciamos trará uma nova atitude do direito, inclusive do Poder Judiciário, que deverá ressignificar antigos conceitos e aprender com novas semânticas relacionadas aos problemas atuais. No entanto, não podemos abrir mão da autonomia do Direito, vale dizer, a resposta adequada para os problemas somente pode passar pelo crivo do código jurídico, sem uma cooptação da moral, da economia e da política. Somente mantendo a autonomia do direito e julgando o caso de acordo com o código direito/não-direito (recht/unrecht) - no caso da jurisdição constitucional, constitucionais ou inconstitucionais - sem relativizações/mediações de cunho moral, econômico, religioso, etc., conseguiremos uma atuação dentro dos quadrantes democráticos. 


\section{DEMOCRACIA, CRISE POLÍTICA E JURISDIÇÃO CONSTI- TUCIONAL NO BRASIL PÓS-2013}

Vivemos um momento político de descredibilidade nas instituições estatais que, a partir das manifestações populares de 2013, ficou escancarado e levou a uma nova reflexão sobre a cena político-jurídica. Leonardo Avritzer levanta cinco hipóteses que conduziram nossa democracia a impasses: "[...] [1] os limites da do presidencialismo de coalizão, isto é, a deslegitimação da forma de fazer alianças, característica da democracia brasileira desde 1994; [2] os limites da participação popular na política, que tem crescido desde 1990 e é bem-vista pela população, mas não logra modificar sua relação com a representação; [3] os paradoxos do combate à corrupção, que avança e revela elementos dramáticos da privatização do setor público no país, os quais terminam por deslegitimar ainda mais o sistema político; [4] as consequências da perda de status das camadas médias que passaram a estar mais próximas das camadas populares a partir do reordenamento social provocado pela queda da desigualdade; por fim, [5] o novo papel do Poder Judiciário na política"(AVRITZER, 2016, p.9). Em momentos em que questões de governabilidade e políticas são colocadas à prova o direito transforma essas comunicações do entorno em comunicações do ambiente ressignificando-as.

Uma grave crise da democracia representativa se entranha entre nós com o distanciamento entre representantes e representados, a perda da centralidade da política para o discurso econômico na arena política, o afastamento dos partidos políticos de suas ideologias e a despolitização da esfera pública (BAHIA, NUNES, 2010; MAGALHÃES, 2017).

Como a jurisdição constitucional reage diante de tais circunstâncias políticas? Acreditar que o Supremo Tribunal Federal ficará alheio a tal horizonte de experiência é simplesmente desconsiderar a realidade das instituições. Nossa hipótese é de que, durante crises políticas, há reações por parte do Supremo Tribunal Federal no exercício da jurisdição constitucional que prejudicam sua legitimidade democrático-constitucional.

A primeira reação é o chamado populismo judiciário em que a jurisdição constitucional acaba atuando para satisfazer a anseios de certas parcelas da sociedade (quando não apenas do oligopólio de mídia traves- 
tido de "opinião pública"). Em contrariedade, a jurisdição constitucional deve agir de forma contramajoritária em sociedades plurais e complexas como a nossa. Sinais assim transparecem em decisões como a relativização da presunção de inocência; a cassação de mandato de deputados condenados criminalmente (ao passo que a Constituição diz que a perda do mandato depende de decisão da Casa Legislativa); a não apreciação do mérito sobre abusos/ilegalidades no processo de impeachment da Presidente Dilma Rousseff ${ }^{6}$.

A segunda reação da jurisdição constitucional em tempos de crise política é a cooptação da Corte pelos discursos econômicos contrários a direitos individuais ou sociais. Em caso de conflito, argumentos econômicos sempre levarão a jurisdição constitucional a julgar de acordo com o ideário econômico e não de acordo com as comunicações do direito.

Para entendermos a característica do populismo judicial e sua relação com a legitimidade é preciso recorrer às clássicas lições de Max Weber. A dominação legítima, segundo Weber, pode ser do tipo tradicional, a racional por meio da lei e a carismática. Neste sentido, a dominação é uma forma de se condicionar a ação dos dominados de forma que os dominados vejam no conteúdo das ações dos dominadores suas próprias ações (WEBER, 1999, p. 191). Com o desencantamento do mundo pela modernidade ${ }^{7}$, foi necessária a racionalização de todos os aspectos da vida social e política. A racionalização do mundo, portanto, se dá através das leis e regras sociais que reconhecem que a legitimação e a autoridade estão no cargo e não na pessoa que o ocupa. 0 poder, portanto, é exercido de modo impessoal, remetendo-se às instituições burocráticas (WEBER, 1999).

Com efeito, o populismo está estritamente relacionado com a dominação de tipo carismática. A dominação carismática é realizada em caráter pessoal, tendo em vista uma determinada missão. Assim, o carisma do líder levará a que sua missão seja considerada sagrada, transformando-se em um dogma ou uma doutrina que não pode ser contestada, desde que, com êxito, realize atos heroicos ou milagres (WEBER, 1999, p. 324-326) ${ }^{8}$. Os seguidores do líder carismático encaram-no como portador de uma força sobrenatural para conduzir o povo a uma missão determinada, sem que o próprio povo participe da missão. É uma missão pessoal e irrenunciável. 
Por mais que se tente ligar a dominação carismática com as sociedades pré-capitalistas, não há nenhum empecilho para que as sociedades modernas também sejam dominadas pelo carisma de alguém, ainda podendo haver a combinação das três espécies de dominação legítima. Segundo Max Weber "a dominação carismática não se limita, de modo algum, às fases primitivas do desenvolvimento, bem como não podem ser colocados simplesmente numa linha evolucionária, um atrás do outro, os três tipos fundamentais da estrutura de dominação, aparecendo eles, ao contrário, combinados um com o outro de forma mais variada"(WEBER, 1999, p. 342). Assim, a combinação entre os tipos de dominação legítima no mesmo espaço-temporal é comum e apresenta-se de uma forma complexa.

Em uma perspectiva político-nacional o populismo enquanto característica de forma de governar sempre teve relação com a perda da representatividade da classe dirigente tornando-se uma classe dominante parasitária e, ao mesmo tempo, a presença de um líder carismático com a possibilidade de um efetivo alcance de significação social. Dizendo com um olhar histórico-conceitual "é sempre a exaltação de uma pessoa na qual esta aparece como a imagem desejada para o Estado. É uma pobre ideologia que revela claramente a ausência total de perspectivas para o conjunto da sociedade" (WEFFORT, 2003, p. 36). Ainda mais triste é quando o populismo parte de um poder que não tem necessariamente a função de representar a sociedade tal qual é o Poder Judiciário.

Sintomático da saída populista da jurisdição constitucional no Brasil é o fato de que, em meio a grave crise político-institucional, a maioria das decisões que resvalariam na separação de poderes e em questões de grande clamor social foram tomadas por decisões monocráticas por Ministros do Supremo Tribunal Federal, mitigando a colegialidade que deve presidir uma Corte Constitucional.

Como já caracterizou Conrado Hubner Mendes, o Supremo Tribunal Federal se tornou formado por onze ilhas (MENDES, 2010), apresentando um grau elevado de decisões individuais que, evidentemente, passam a ser contestáveis diante do princípio do juiz natural. À evidência, a transmissão dos julgamentos do Supremo Tribunal Federal pela TV Justiça, criada pela Lei 10.461/2002, e a própria dinâmica de julgamento seriatim que apresenta o julgamento em texto composto com a opinião 
de cada Ministro levou a uma Corte Constitucional singular no mundo. A individualidade nos julgamentos passou a ser a regra.

Por exemplo, o julgamento da liminar na Ação Cautelar 4070 que afastou o Deputado Eduardo Cunha da Presidência da Câmara e suspendeu seu mandato como Deputado Federal foi tomada pelo Min. Teori Zavascki ${ }^{9}$, posteriormente a liminar foi referendada pelo plenário ${ }^{10}$ - o mesmo Tribunal (com a mesma composição, inclusive), seis meses depois decidiu que não caberia o afastamento do Presidente do Senado, Renan Calheiros, apesar das questões discutidas (ratio decidendi) em um e outro caso serem as mesmas: o Relator, Min. Marco Aurélio, seguindo o precedente do caso Cunha, havia dado liminar para afastar o Presidente do Senado; este, por sua vez, (ADPF 402-MC). Outro caso: a suspensão da nomeação de um Ministro de Estado, no caso o ex-Presidente Lula, por meio também de medida liminar monocrática proferida pelo Min. Gilmar Mendes no Mandado de Segurança $34.070^{11}$ que, até o fechamento do presente texto, não teve sua liminar referendada pelo plenário. Também a determinação da prisão de Senador durante seu mandato por meio de decisão liminar monocrática proferida na Ação Cautelar 4039 pelo Ministro Teori Zavascki ${ }^{12}$ referendada pelo plenário ${ }^{13}$.

Os Ministros parecem encarnar a crença de que estão em uma missão para realizar a dominação carismática. Em nosso caso, a missão seria uma jornada judicial contra a corrupção, uma batalha travada entre uma pessoa especial, seja pelo saber técnico ou mesmo pelo cargo ocupado, contra todo um sistema corrupto com o intuito de salvar o povo do sistema político corrupto.

Pouco importa, nessa cruzada, que sejam mantidas as razões legal e constitucional que devem nortear a nossa sociedade. A principal questão é que o juiz deve encontrar ressonância de suas decisões na opinião popular e não nos limites normativo-constitucionais. Não só, portanto, um ministro representaria a missão de salvar a sociedade dos efeitos nefastos da corrupção causada pelos demais poderes, mas também o próprio Supremo Tribunal Federal enxerga-se como instituição salvadora de nossa comunidade política, passando a ser bem vista aos olhos do "povo" e, ao mesmo tempo, satisfazendo a "opinião pública". 
Não é outro o sentido da decisão, absolutamente contrária à Constituição e aos tratados internacionais de direitos humanos ratificados pelo Brasil, tomada no Habeas Corpus 126.292 pelo Plenário que permitiu a execução provisória da pena após o julgamento da $2^{\underline{a}}$ instância pelo réu condenado em processo penal, em razões de eficiência da lei processual-penal e eficácia no combate à corrupção ${ }^{14}$ - é dizer, fundados em razões de política e não de direito (DWORKIN, 2005). Quando um Tribunal decide não com base no que dizem a Constituição e as leis mas sim em argumentos de outras sorte, como pragmáticos, econômicos, sociais, religiosos, há uma corrupção no código do direito, que passa a ser colonizado por esses outros sistemas. A decisão do STF nesse caso se deu (quase) exclusivamente em razão de questões como "os advogados de defesa abusam dos recursos para atrasar o cumprimento das condenações e isso beneficia os mais ricos e os condenados por corrupção".

Populismo judicial, em breves linhas, é quando o Poder Judiciário se arroga na missão de salvar a sociedade dos poderes políticos e, para tanto, utiliza-se da opinião pública, implicitamente, para legitimar suas decisões, seja desconsiderando ou dentro das balizas constitucionais, buscando exercer um poder carismático-pessoal e não impessoal em grave violação ao juiz natural.

Além de resolver o problema político-representativo da democracia e apoiado em puro populismo, o Supremo Tribunal Federal busca, também, resolver problemas econômicos, mesmo que às custas de eventuais direitos sociais e individuais historicamente conquistados através de lutas políticas.

Ora, o Supremo Tribunal Federal julgou questões envolvendo problemas econômico-financeiros pelos poderes públicos. Estados apresentaram pedidos de Mandado de Segurança para que a União fosse obstada de cobrar juros compostos e passasse a cobrar juros simples. Então, foi concedida medida liminar nos MS 34023, MS 34110 e MS 34.122 para que a União não aplicasse qualquer sanção aos Estados até o julgamento definitivo da questão pelo Supremo Tribunal Federal. Também há que se lembrar o julgamento das liminares proferidas pela Ministra Rosa Weber nas Ações Cíveis Originárias 2934, 2935, 2936, 2938, 2940, 2941 e 2942 para que a União depositasse o valor devido aos Estados de valores repatriados pela $13.254 / 2016^{15}$. 
Com um argumento eminentemente econômico-pragmático, o Supremo Tribunal Federal em julgamento do RE 693456 em Repercussão Geral fixou o sentido de que cabe ao Poder Público proceder descontos de servidores públicos em greve, exceto se houver manifesta ilegalidade pelo poder público: “A administração pública deve proceder ao desconto dos dias de paralisação decorrentes do exercício do direito de greve pelos servidores públicos, em virtude da suspensão do vínculo funcional que dela decorre, permitida a compensação em caso de acordo. 0 desconto será, contudo, incabível se ficar demonstrado que a greve foi provocada por conduta ilícita do Poder Público" (Tema 531).

Assim, também vedou a possibilidade de desaposentação daqueles segurados que, aposentados, continuaram vertendo contribuições para a previdência social. No fundo, entendeu o STF que nosso regime previdenciário tem o caráter solidário e não contributivo. Fixou-se, assim, a seguinte conclusão no RE 661256: "No âmbito do Regime Geral de Previdência Social - RGPS, somente lei pode criar benefícios e vantagens previdenciárias, não havendo, por ora, previsão legal do direito à 'desaposentação', sendo constitucional a regra do art. 18, § $2^{\circ}$, da Lei no 8.213/91" (Tema 503).

A aliança do populismo judicial e a defesa dos argumentos econômicos em detrimento dos argumentos de princípio são nefastos para o exercício democrático da jurisdição constitucional. A crise política trouxe a reboque a deslegitimação da jurisdição constitucional pelo Supremo Tribunal Federal que, no entanto, só poderá retornar os trilhos constitucionais atuando contramajoritariamente, encarando os direitos fundamentais como trunfos contra a maioria.

\section{CONSIDERAÇõES FINAIS}

Em momentos de instabilidade política e ruptura institucional-democrática é imprescindível que retornem as discussões e reflexões acadêmicas à temática da legitimidade da jurisdição constitucional. No presente trabalho buscamos refletir e observar como tem atuado a juris- 
dição constitucional no Brasil diante dos acontecimentos políticos e de que forma a política pode influenciar na atuação do Supremo Tribunal Federal. A crise política instalada no Brasil após o ano de 2013 trouxe novos elementos que precisam ser analisados, refletidos e debatidos no âmbito da teoria constitucional. 0 primeiro elemento jurídico-político é a ideia de populismo judicial e o segundo elemento é a primazia dos argumentos econômico-financeiros na jurisdição constitucional. Tanto em um como noutro caso o uso de fundamentos não jurídicos por sobre o sistema do direito corrompem esse sistema e acabam com sua autonomia funcional.

Tais elementos jurídico-políticos provocam uma problemática na legitimidade democrática da jurisdição constitucional que, como vimos, já nasce sendo um paradoxo no sentido luhmanniano. Desparadoxar dependerá da manutenção da autonomia do sistema jurídico que tem seu sentido último na Constituição, cuja missão de garanti-la depende em grande medida da jurisdição constitucional contramajoritária e mantendo a normatividade integral do projeto constitucional.

É exatamente em momentos de instabilidade política que o direito poderá reforçar sua autonomia e a jurisdição constitucional conquistar legitimidade dentro dos referenciais jurídicos, mantendo íntegro o projeto constitucional em referência.

\section{NOTAS}

1 Exemplo elucidativo do clima de hostilidade do controle de constitucionalidade é a edição na França da Lei 16 de 24 de Agosto de 1790 instituindo o refere legislatif que tinha o condão de retirar do Poder Judiciário a função de interpretar a lei. Também a criação de uma Corte de Cassação como órgão subordinado ao Poder Legislativo para anular qualquer interpretação de lei que violasse sua expressão textual fecha um corpo de medidas contra o Poder Judiciário que, de certo, impediram a absorção dos princípios enunciados em Marbury x Madison (HORTA, 2010. p. 147).

2 "Se a própria justiça eleva-se, desse modo, à condição de instância moral superior da sociedade, ela é subtraída aos mecanismos sociais de controle aos quais - no campo ideal - todos os aparelhos estatais de uma forma de organização política democrática deveriam se submeter. Na dominância de uma justiça que exerce um Direito superior moralmente enriquecido em relação a outros poderes estatais que se ocupam unicamente com o Direito ordinário - e em relação ao resto da sociedade - é notória a regressão ao modelo social pré-democrático de integração" (MAUS, 2010.p. 18)

3 A seguinte passagem de Factidad y Validez representa o seu pensamento: “La discusión acerca del activismo o del self-restraint del Tribunal Constitucional no puede efectuarse en abstracto. Si se entiende la Constitución como interpretación y configuración de un sistema de derechos mediante el que se hace valer la conexión interna de autonomía pública y autonomía privada, 
una jurisprudencia constitucional ofensiva no sólo no resultará perjudicial en los casos en que se trate de hacer valer el procedimiento democrático y la forma deliberativa de formación de la opinión y de voluntad política, sino que incluso viene normativamente exigida (HABERMAS, 2010. p. 354)

4 LUHMANN, Niklas. Introdução à teoria dos sistemas. Trad. Ana Cristina Arantes Nasser. Petropólis: Vozes, 2009. Também a seminal obra: LUHMANN, Niklas. La sociedad de la sociedad. México: Herder, 2007.

5 LUHMANN, Niklas. La sociedad de la sociedad. México: Herder, 2007. p. 626-627.

6 Participando de Banca na Faculdade de Direito da UFMG certo Ministro do STF disse que achar que o Tribunal iria se manifestar contra a decisão do Congresso no processo de impeachement quando $2 / 3$ de Deputados e Senadores e $80 \%$ da população (não sabemos de onde o Ministro retirou este último dado) eram a favor seria pensar nos Ministros como "heróis mascarados". Ora, ao contrário do que ele disse, o compromisso do STF deve ser com a constitucionalidade e legalidade dos atos e não com - pretensas - maiorias.

7 WEBER, Max. A ética protestante e o 'espírito' do capitalismo. São Paulo: Companhia das Letras, 2004.

8 WEBER, Max. Economia e sociedade: fundamentos da sociologia compreensiva. Vol. 2. Brasília: Editora UNB, 1999. p. 324-326.

9 Decisão disponível em: <http://s.conjur.com.br/dl/ac-4070-teori-afasta-cunha.pdf>, acesso em 07 de Maio de 2016.

10 STF, AC 4070/DF, rel. Min. Teoria Zavascki, julgamento 05/05/2016, publicação DJe -225 $21 / 10 / 2006$.

11 Decisão disponível em:<http://www.stf.jus.br/arquivo/cms/noticiaNoticiaStf/anexo/ms34070. pdf>, acesso em 19 de Maio de 2017.

12 Decisão disponível em: <http://www.stf.jus.br/arquivo/cms/noticiaNoticiaStf/anexo/Acao_Cautelar_4039.pdf>, acesso em 19 de Maio de 2017.

13 “CONSTITUCIONAL. PROCESSUAL PENAL. PRISÃO CAUTELAR. SENADOR DA REPÚBLICA. SITUAÇÃO DE FLAGRÂNCIA. PRESENÇA DOS REQUISITOS DE PRISÃO PREVENTIVA. INAFIANÇABILIDADE. CABIMENTO DA PRISÃO CAUTELAR (ART. 53, § 2 , DA CF). DECISÃO REFERENDADA" (STF, AC 4039, Rel. Min. Teori Zavascki, j. 25/11/2015, DJe. 12.05.2016).

14 Decisão com a ementa: "CONSTITUCIONAL. HABEAS CORPUS. PRINCÍPIO CONSTITUCIONAL DA PRESUNÇÃO DE INOCÊNCIA (CF, ART. 5ํ, LVII). SENTENÇA PENAL CONDENATÓRIA CONFIRMADA POR TRIBUNAL DE SEGUNDO GRAU DE JURISDIÇÃO. EXECUÇÃO PROVISÓRIA. POSSIBILIDADE. 1. A execução provisória de acórdão penal condenatório proferido em grau de apelação, ainda que sujeito a recurso especial ou extraordinário, não compromete o princípio constitucional da presunção de inocência afirmado pelo artigo 5o, inciso LVII da Constituição Federal.

2. Habeas corpus denegado." (STF, plenário, HC 126.292/SP, rel. Min. Teori Zavascki, j. 17 de Fevereiro de 2016).

15 Referências disponíveis em: http://s.conjur.com.br/dl/retrospectiva-barroso-2016-parte.pdf, acesso em 19 de Maio de 2017. 


\section{REFERÊNCIAS}

ALEXY, Robert. Balancing, constitucional review, and representation. Oxford University Press and New York University School of Law, Number 4, p. 572-581, 2005.

ALEXY, Robert. Conceito e validade do direito. Trad. Gercélia Batista de Oliveira Mendes. São Paulo: WMF Martins Fontes, 2009.

ALMEIDA, Frederico de. A nobreza togada: as elites jurídicas e a política da justiça no Brasil. Tese de Doutorado em Ciência Política - USP, orientada pela Profa. Dra. Maria Tereza A. Sadek, 2010. Disponível em: <https://goo.gl/4xSLnc>.

AVRITZER, Leonardo. Impasses da democracia no Brasil. Rio de Janeiro: Civilização Brasileira, 2016.

BACHA E SILVA, Diogo. Ativismo no controle de constitucionalidade: a transcendência dos motivos determinantes e a ilegítima apropriação do discurso de justificação pelo STF. Belo Horizonte: Arraes editores, 2013.

MAC-GREGOR, Eduardo Ferrer. El control difuso de convencionalidad en el estado constitucional. Observatório da jurisdição constitucional. Brasília: IDP, Ano 4, 2010/2011.

BAHIA, Alexandre Gustavo Melo Franco de Moraes, BACHA E SILVA, Diogo, CATTONI DE OLIVEIRA, Marcelo Andrade, FERNANDES, Bernardo Gonçalves. 0 caso Cunha no STF e a defesa da integridade constitucional: a decisão liminar na AC 4.070 e o sentido adequado das prerrogativas e imunidades parlamentares. Disponível em: <http://emporiododireito.com.br/caso-cunha-no-stf>, acesso em 19 de Maio de 2017.

BAHIA, Alexandre Gustavo Melo Franco Moraes, BACHA E SILVA, Diogo. CATTONI DE OLIVEIRA, Marcelo Andrade. Judicialização da política, jurisprudencialismo processual penal e ativismo com sinal trocado: o Supremo Tribunal Federal e a crise política. In: VIEIRA, José Ribas, CAMARGO, Margarida Maria Lacombe, ANDRADE, Mário Cesa (orgs.). 0 direito e a instabilidade política: experiências, desafios e perspectivas. Belo Horizonte: Forum, 2016c. 
BAHIA, Alexandre; NUNES, Dierle. Crise da democracia representativa - infidelidade partidária e seu reconhecimento judicial. Revista Brasileira de Estudos Políticos, n. 100, jan/jun de 2010.

BAHIA, Alexandre; Silva, Diogo Bacha e. Supremo Tribunal Federal, Devido Processo Legislativo e a Teoria do Direito como Integridade: em busca da promoção dos valores democráticos. In: OMMATI, José E. Medauar (org.). Ronald Dworkin e o direito brasileiro. Rio de Janeiro: Lumen Juris, 2016.

BAHIA, Alexandre; SILVA, Diogo Bacha e; NUNES, Dierle; GOMES, Renata Nascimento (orgs.). Processo e Constituição: estudos sobre a judicialização da saúde, da educação e dos direitos homoafetivos. Florianópolis: Empório do Direito, 2015.

BICKEL, Alexander M. The Least Dangerous Branch. 2. ed. New Haven: Yale University Press, 1986.

BONAVIDES, Paulo. Jurisdição constitucional e legitimidade (algumas observações sobre o Brasil). Estudos Avançados, 18, n. 51, p. 127-150, maio/ago., 2004.

CAPPELLETTI, Mauro. 0 controle judicial de constitucionalidade das leis no direito comparado. Tradução de Aroldo Plinio Gonçalves. 2. ed. Porto Alegre: Sergio Antonio Fabris editora, 1999.

CATTONI DE OLIVEIRA, Marcelo Andrade. Devido processo legislativo: uma justificação democrática do controle de constitucionalidade das leis e do processo legislativo. 3. ed. Belo Horizonte: Fórum, 2016.

CATTONI DE OLIVEIRA, Marcelo; BAHIA, Alexandre; BACHA E SILVA, Diogo. 0 Impeachment e o Supremo Tribunal Federal: história e teoria constitucional brasileira. Florianópolis: Empório do Direito, 2016a.

CATTONI DE OLIVEIRA, Marcelo; BAHIA, Alexandre; BACHA E SILVA, Diogo. Autocracia judicial? 0 poder judiciário e o risco do estado de exceção. Empório do Direito, 27.09.2016b. Disponível em: <https://goo.gl/bnTleH>.

CRUZ, Álvaro Ricardo de Souza. Jurisdição constitucional democrática. Belo Horizonte: Editora Del Rey, 2004. 
DWORKIN, Ronald. A justiça de toga. Trad. Jefferson Luiz Camargo. São Paulo: WMF Martins Fontes, 2010.

DWORKIN, Ronald. Uma questão de princípio. Trad. Luis Carlos Borges. 2. ed. São Paulo: Martins Fontes, 2005.

ELY, John Hart. Democracia e desconfiança: uma teoria judicial do controle de constitucionalidade. trad. Juliana Lemos. São Paulo: WMF Martins Fontes, 2010.

ENTERRÍA, Eduardo García. La Constitución como norma y el Tribunal Constitucional. 4. ed. Madri: Civitas, 2006.

GUILLAUME, Marc. La question prioritaire de constitutionnalité. Disponível em: http://www.conseil-constitutionnel.fr/conseil-constitutionnel/root/ bank_mm/QPC/qpc_mguillaume_19fev2010.pdf, acesso em 07/05/2017.

HABERMAS, Jürgen. Facticidad y Validez: sobre el derecho y el Estado democrático de derecho en términos de teoría del discurso. Trad. Manuel Jimenez Redondo. 6a ed. Madri: Trotta, 2010.

HAMILTON, Alexander; MADISON, James; JAY, John. O Federalista. Belo Horizonte: Líder, 2003.

HORTA, Raul Machado. Direito constitucional. 5. ed. Belo Horizonte: Editora Del Rey, 2010.

KELSEN, Hans. Jurisdição constitucional. Trad. Alexandre Krug. São Paulo: Editora Martins Fontes, 2007.

KRAMER, Larry D. Constitucionalismo popular y control de constitucionalidad. Trad. Paola Bergallo. Madri: Marcial Pons, 2011.

LUHMANN, Niklas. A Constituição como Aquisição Evolutiva. Tradução livre feita por Menelick de Carvalho Netto. La costituzione come acquisizione evolutiva. In: ZAGREBELSKY, Gustavo (coord.) (et al.). Il Futuro Della Costituzione. Torino: Einaudi, 1996.

LUHMANN, Niklas. A terceira questão - o uso criativo dos paradoxos no Direito e na História do Direito. Estudos jurídicos, v. 39, n. 1, p. 42-52, jan./jun. 2006. 
LUHMANN, Niklas. El derecho de la sociedad. Trad. Javier Torres Nafarrete. 2. ed. Ciudad de Mexico: Herder, 2005.

LUHMANN, Niklas. Introdução à teoria dos sistemas. Trad. Ana Cristina Arantes Nasser. Petropólis: Vozes, 2009.

LUHMANN, Niklas. La sociedad de la sociedad. México: Herder, 2007.

MACIEL, Adhemar Ferreira. 0 acaso, John Marshall e o controle de constitucionalidade. Revista de Informação Legislativa, Brasília, a. 43, n. 172, p. 37-44, out./dez. 2006.

MAGALHÃES, José Luiz Quadros. Dilemas do Federalismo Brasileiro: território e diversidade na construção de uma democracia real. In: NETO, Alfredo Copetti, LEITE, George Salomão, LEITE, Glauco Salomão (orgs.). Dilemas na Constituição. Belo Horizonte: Forum, 2017.

MAGALHÃES, Jose Luiz Quadros. Jurisdição Constitucional e Federalismo. In: Constituição e processo: a contribuição do processo ao constitucionalismo democrático brasileiro. Belo Horizonte: 2009, Editora Del Rey.

MAGALHÃES, Juliana Neuenschwander. A formação do conceito de direitos humanos. Juruá: Curitiba, 2013.

MAUS, Ingeborg. 0 judiciário como superego da sociedade. Tradução de Geraldo de Carvalho. Rio de Janeiro: Lumen Juris, 2010.

MENDES, Conrado Hübner. Onze Ilhas . Folha de São Paulo: tendências e debates, São Paulo, 01.02.2010, disponível em: http://avaranda.blogspot.com/2010/02/ conrado-hubner-mendes.html.

NOVAES, Adauto. 0 esquecimento da política. Rio de Janeiro: Agir, 2007.

PINTO, Élida Graziane; BAHIA, Alexandre; SANTOS, Lenir. O financiamento da saúde na Constituição de 1988: um estudo em busca da efetividade do direito fundamental por meio da equalização federativa do dever do seu custeio mínimo. A\&C. Revista de Direito Administrativo \& Constitucional, v. 16, p. 209-237, 2017. 
POST, Robert, SIEGEL, Reva. Popular Constitutionalism, departmentalism, and judicial supremacy. California Law Review, 2004, 92, p. 1027- 1043.

RAMOS, Elival da Silva. Controle de constitucionalidade no Brasil: perspectivas de evolução. São Paulo: Editora Saraiva, 2010.

RESTREPO, Ricardo Sanín, HINCAPIE, Gabriel Mendés. La Constitución Encriptada. Nuevas formas de emancipación del poder global. Revista de Derechos humanos y estúdios sociales. Ano IV, n. 8, Julio-Deciembre 2012.

SIMIONI, Rafael L. Curso de Hermenêutica Jurídica Contemporânea: do positivismo clássico ao pós-positivismo jurídico. Curitiba: Juruá, 2014.

WALDRON, Jeremy. Judicial review and judicial supremacy. Disponível em: http://www.catolicalaw.fd.lisboa.ucp.pt/download/en/judicial-review-andjudicialsupremacy-jeremy-waldron.pdf. Acesso em: Maio de 2017.

WALDRON, Jeremy. The Core of the Case against Judicial Review. Yale Law Journal, v. 115, 1346-1406, 2006.

WEBER, Max. A ética protestante e o 'espírito' do capitalismo. São Paulo: Companhia das Letras, 2004.

WEBER, Max. Economia e sociedade: fundamentos da sociologia compreensiva. Vol. 2. Brasília: Editora UNB, 1999.

WEBER, Max. Economia e sociedade: fundamentos da sociologia compreensiva. Vol. 1. Brasília: Editora UNB, 1999.

WEFFORT, Francisco. 0 populismo na política brasileira. 5. ed. Rio de Janeiro: Paz e Terra, 2003.

Recebido em: 26-5-2017

Aprovado em: 15-1-2018 


\section{Diogo Bacha e Silva}

Doutorando em Direito pela UFRJ; mestre em Constitucionalismo e Democracia pela FDSM, Professor do Curso de Direito da Faculdade de São Lourenço, Advogado, e-mail: diogobacha@ig.com.br.

\section{Alexandre Gustavo Melo Franco Moraes Bahia}

Doutor em Direito pela UFMG. Professor na UFOP e IBMEC-BH. Coordenador do Programa de Mestrado "Novos Direitos, Novos Sujeitos" da UFOP. Bolsista de Produtividade do CNPq. E-mail: alexprocesso@gmail.com.

Programa de Pós-Graduação em Direito da Universidade Federal do Rio de Janeiro (UFRJ)

Rua Moncorvo Filho, no 08, Térreo, Centro, Rio de Janeiro/RJ, CEP 20.211-340. 
